\title{
Effect of dietary protein level on growth and energy utilization by Litopenaeus stylirostris under laboratory conditions
}

\author{
F. Gauquelin ${ }^{a}$, G. Cuzon ${ }^{a}{ }^{*}$, G. Gaxiola ${ }^{b}$, C. Rosas ${ }^{b}$, L. Arena ${ }^{b}$, D.P Bureau ${ }^{c}$ and J.C. \\ Cochard $^{\mathrm{a}}$
}

\author{
a Ifremer/COP, BP 7004 Taravao, Tahiti, French Polynesia \\ b UNAM Unidad Multidisciplinaría de Docencia e Investigación, Facultad de Ciencias, Sisal, Yucatán Lab \\ Ecophysiologia, Sisal, Yucatan, Mexico \\ ${ }^{\mathrm{c}}$ Fish Nutrition Research Lab, University of Guelph, Ontario, Canada N1G 2W1
}
*: Corresponding author : Cuzon G., Tel.: +33 6895460 35; fax: +33 6895460 99, email address : Gerard.Cuzon@ifremer.fr

\begin{abstract}
:
A study was conducted using a bioenergetics approach to generate information on energy requirement and feed utilization of Litopenaeus stylirostris. Animals (initial mean weight $21 \pm 1 \mathrm{~g}$ were fed ad libitum six experimental diets, ranging from 25 to $58 \%$ crude protein (CP), for 50 days.

Weight gain increased from 21 to $30 \mathrm{~g}$ with increasing dietary protein level. Survival rates averaged $80 \%$. Basal metabolism (HeE) and heat increment of feeding (HiE) were monitored using respirometry. HeE was on average $1 \mathrm{~kJ}$ shrimp ${ }^{-1}$ day $^{-1}$ or $47 \mathrm{~kJ} \mathrm{~kg} \mathrm{live} \mathrm{weight}^{-1}$ day $\left(22 \mathrm{~kJ} / \mathrm{kg}^{0.8} \cdot \mathrm{d}^{-1}\right)$, slightly more than what is observed in fish. HiE averaged $0.2 \mathrm{~kJ}$ shrimp ${ }^{-1}$ day $^{-1}$ or $10 \mathrm{~kJ} \mathrm{~kg} \mathrm{live} \mathrm{weight}{ }^{-1} \mathrm{day}^{-1}$ $\left(4 \mathrm{~kJ} / \mathrm{kg}^{0.8} \mathrm{~d}^{-1}\right)$. It represented $31 \%$ and $12 \%$ digestible energy intake (DEI) for shrimp fed on $58 \% \mathrm{CP}$ and $25 \%$ CP diet respectively. Non-fecal (UE + ZE) energy calculated on the basis of $\mathrm{N}$-ammonia excretion averaged $0.2 \mu \mathrm{g} \mathrm{N}$-ammonia/g dry wt./mn or $25 \mathrm{~J} \mathrm{live} \mathrm{shrimp}^{-1}$ day $^{-1}$ in fasting stage and increased to $40 \mathrm{~J}$ in post-prandial stage. Ammonia production increased with increasing dietary crude protein (CP). The O:N ratio indicated that protein was increasingly used as an energy substrate as $\mathrm{CP}$ increased. The information was used to construct an energy budget for shrimp fed a protypical $40 \%$ $\mathrm{CP}$ diet. Gross energy intake (IE) was estimated at $6.5 \mathrm{~kJ}$ live shrimp ${ }^{-1}$ day $^{-1}$; digestible energy intake $(\mathrm{DEI})$ at 5 , urinary and branchial excretion $(\mathrm{UE}+\mathrm{ZE})$ at 1.2, total heat production (HE) at 3.2; recovered energy (RE) at 0.6 (or $11 \% \mathrm{DEI})$. L. stylirostris adults issued from domesticated strain appeared to be more efficiently utilizing (i.e. converting into carcass energy) protein than carbohydrates. This preliminary energy budget can be used to construct theoretical feed requirement and waste outputs model for $L$. stylirostris.
\end{abstract}

Keywords: L. stylirostris; Dietary protein; Growth; Excretion; Respiration 


\section{Introduction}

The blue shrimp L. stylirostris was domesticated in Tahiti over the past 25 y and led to identify a specific pathogen resistant strain (SPR40). This species is currently farmed in semi-intensive conditions in New Caledonia. However, a gradual increase of mortality has been noticed since 1993 (Mermoud et al., 1998). High mortality rates appear to be related to a progressive degradation of the pond ecosystem and water quality problems. This degradation is likely partly due to management, overfeeding, and/or variation in feed quality. Incomplete removal of mud and/or insufficient pond drying time between production cycles can affect water quality and productivity. However, poor feeding management (excessive feeding) and/or poor utilization of feed by the animal themselves (Burford and Williams, 2001) remains a major concern.

There is consequently a need to improve our knowledge on feed utilization by L.stylirostris. Bioenergetics approaches have been effectively used to predict growth, feed requirement and utilization, and waste outputs of different fish species (Cho and Kaushik, 1990; Cho, 1991; Cho and Bureau, 1998; Elliot and Hurley, 1999; Kaushik, 1998; Lupatsch et al., 1998; Cui and Xie, 1999; Bureau et al.,2002; Zhou et al., 2005). In contrast, for crustacean species, notably penaeid shrimp information is limited (Bureau et al., 2000). Data from crustaceans are difficult to interpret due to wide differences in species, development stages, feed composition, feeding rate and estimation of feed consumption then nutrient intake. And because of a lack of data on L.stylirostris some estimates on main parameters collected on different species were necessary to review briefly in order to set a same order of magnitude for each parameters contributing to the energy budget. Sick et al. (1972) estimated HP (HE, HeE+HiE) feeding Macrobrachium larvae (7mg av. wt) to be on average $0.2 \mathrm{~J} \mathrm{mg}^{-1}$ live weight day ${ }^{-1}$. Similar data were reported presented for postlarvae of the same species, since Stephenson and Knight (1980) observed that Macrobrachium postlarvae respired $0.24 \mathrm{~J} \mathrm{mg}^{-1}$ live wt day $^{-1}$. These values appeared to be high in comparison with estimated HE of lobster post-larvae (stages IV and V) at about $0.06 \mathrm{~J}$ postlarvae $^{-1}$ day $^{-1}$ (Capuzzo et al. 1979). But Marsh et al.(2001) measured $3 \mathrm{~J} \mathrm{larvae}^{-1}$ day $^{-1}$ from zoea to megalope (2 wk) stages of Hemigrapsus crassipes. Similarly, F.brasiliensis larvae respired $3 \mathrm{~J} \mathrm{larvae}^{-1} \mathrm{day}^{-1}$ (Gaxiola et al., 2002). Heat production (HE) was calculated to be $8-12 \%$ above the resting rate (HeE) in P.esculentus (Dall, 1986; Dall and Smith, 1986). Resting rate of P.vannamei juveniles consumed $21 \mathrm{~J}$ shrimp-1h-1 reported on a $15 \mathrm{~d}$ period (Comoglio et al., 2004). Molting (SE) depending directly on water temperature, has a determinant effect on metabolism. P.monodon juveniles used $26 \%$ accumulated energy for molting; Read and Caulton (1980) calculated approximately $1.4 \mathrm{~kJ}$ lost at molt. Nelson (1977) reported an energy loss per molt at around $7.3 \%$ DE with Macrobrachium. Metabolizable energy (ME) intake increased nearly 3 times fold from $19^{\circ} \mathrm{C}$ to $27^{\circ} \mathrm{C}$ with 93 and $247 \mathrm{~J} \mathrm{juv}^{-}$ ${ }^{1}$ day $^{-1}$ respectively on juveniles L.californiensis (Ocampo (1998). Dietary protein level can have a significant effect on energy expenditure too (Hewitt and Irving, 1990; Koshio et al., 1993). In P.japonicus, soy protein concentrate compared to crab protein increased HE (35 and 16\% DE respectively). Heat increment $(\mathrm{HiE})$ was monitored at several protein levels with $P$. setiferus, $P$. 
schmitti, $P$. duorarum, and $P$. notialis postlarvae; there was a direct relation between HiE and dietary protein level whatever species tested (Rosas et al., 1996). P.setiferus postlarvae fed on a $30 \%$ protein diet had lower $\mathrm{HiE}$ compared to shrimp fed 40 or $50 \%$ CP (Rosas et al., 1998). At end, L.stylirostris RE were calculated for $0.3-1.5 \mathrm{~kJ} \mathrm{~d}^{-1}$ from trials with shrimp between 5 to $24 \mathrm{~g}$ average weight (Corraze,1994); this energy for growth is related to protein intake with an optimal DP/DE 20-23mg protein $\mathrm{kJ}^{-1}$ for L.stylirotris or. L vannamei (Cousin, 1995; Cuzon and Guillaume, 1997). L.stylirostris energy expenditure is needed in order to compare with other species such as P.monodon with an optimum growth between 25-28mg protein $\mathrm{kJ}^{-1}$ (Shiau and Peng, 1992) and examine the physiological effect of protein level that would generate information needed to further provide rationale in feed adjustments and minimize wastes output under semiintensive shrimp farming conditions.

\section{Materials and methods}

\subsection{Experimental diets}

Practical diets, fish meal, soybean and wheat based were prepared through combination of two "mash" diets (referred to as diets A and B) in different proportions to obtain the desired final protein levels (Table1). The various diets were coldpressed to produce $2 \mathrm{~mm}$ diameter pellets, which were then dried for 2 hours at $50^{\circ} \mathrm{C}$. The diets were stored at $2^{\circ} \mathrm{C}$ until used. Each dry pellet was estimated to weigh $0.15 \mathrm{~g}$ on average and this average used to calculate feed intake in the metabolic chamber during the respirometry trial.

Shrimp were fed a standard grower shrimp feed for 3 days prior the beginning of experiment. During the experiment, the animals were fed a ration equivalent to $3 \%$ body weight (BW) per day distributed in two discrete meals, in the morning and the late afternoon. Feed wastage was assessed daily by difference between the amount of feed distributed and what remained on the bottom the following day. Feed water stability was assessed and leaching did not exceed $10 \%$ loss dry matter per hour. It was observed that most of the feed was ingested during $10-15 \mathrm{mn}$ after a meal.

\subsection{Animals, Experimental conditions and husbandry}

Animals originated from Tahiti $\mathrm{SPR}^{43}$ strain resistant to IHHN viruses (Weppe et al.,1992) held for 18 generations in captivity. Shrimp were sampled in earthen ponds $\left(600 \mathrm{~m}^{2}\right)$ with a cast net in order to get at least 360 animals average weight $21+/-1 \mathrm{~g}$ and directly allocated into 225-L fibreglass tanks that were used for the growth trial (15 shrimp/tank) for the entire duration of experiment. Stocking density was about 15 shrimp $/ \mathrm{m}^{2}$

Molts were collected every day and frequency of molting per day calculated according the following formulae: $\%$ molts/day $=($ molt number at day $\mathrm{d} / \mathrm{shrimp}$ number at day $\left.\mathrm{d}^{-1}\right)^{\star} 100$ and $\mathrm{N}$ molts $=\%$ (daily molts $/ 100$ ).

Estimation of leftovers was done visually using a scale of $100 \%, 75 \%, 50 \%$ and $0 \%$ leftovers and variation of daily amount of feed distributed was plotted with time.

Feces were collected by siphoning from a large tank holding 15-20 shrimp fed twice a day. Feces were collected $3 \mathrm{~h}$ after the first meal and then another time during the day. The operation was repeated for several days until sufficient amount was collected to allow analysis for celite (Cousin et al., 1996), crude protein and gross energy. 


\subsubsection{Growth trial and rearing conditions}

L.stylirostris shrimp were randomly distributed into 24 experimental tanks, 4 replicates per treatment and 15 shrimp per tank. Each tank was considered as an experimental unit.

The aquatic system was supplied with seawater at 3L/minute (50-100\% renewal/day). Water temperature was maintained at $27^{\circ} \mathrm{C}$ throughout experiment. Photoperiod was $12 \mathrm{~h}$ light: $12 \mathrm{~h}$ dark. Oxygen and flow rates were checked daily. Dissolved oxygen never fell below $7 \mathrm{mg} \mathrm{l}^{-1}$.

\subsubsection{Respirometry trial}

Oxygen consumption of shrimp of shrimp selected at intermolt stage $\mathrm{C}$ was estimated using a a flow-through $\left(0.8 \mathrm{~L} \mathrm{mn}^{-1}\right)$ respirometer made of rectangular PVC tanks with four chambers (2.5-L), one without shrimp (blank) and three replicates for each measure. Dissolved oxygen (DO) readings were taken every $10 \mathrm{mn}$ using an oxymeter Model YSI (5739, Yellow Springs Instruments, OH, USA).

$\mathrm{O}_{2} \mathrm{mg} \mathrm{mn}^{-1}=\left[\mathrm{O}_{2} \text { tank }\left(\mathrm{mg} \mathrm{L}^{-1}\right)-\mathrm{O}_{2} \text { control }\left(\mathrm{mg} \mathrm{L}^{-1}\right)\right]^{\star}$ flow rate $\left(\mathrm{L} \mathrm{mn}^{-1}\right)$

Heat production $(\mathrm{kJ})$ was estimated from oxygen consumption using an oxycalorific coefficient of $13.6 \mathrm{~kJ} \mathrm{~g}^{-1} \mathrm{O}_{2}$.

Ammonia excretion was estimated from water samples taken from the respirometer chamber every half hour. Ammonia-N concentratio was determined according to the method of Solorzano (1969). Evaluation of ammonia excretion using this manual method led to run two cycles of $24 \mathrm{~h}$ as a preliminary asset in order to see the interesting period for monitoring the excretion. Each time a case of cannibalism was observed, recorded value $\left(\mathrm{O}_{2}\right.$ or $\mathrm{N}$-ammonia) was removed from the data set.

Six whole shrimp for each diet were pooled and sampled at beginning and end of experiment and freeze-dried for chemical composition analysis. Nitrogen retention (9 shrimp/49d) was obtained through the following calculation: final weight wet in $\mathrm{g} \mathrm{x}$ concentration in $\mathrm{N}$ final (wet, g/g)-initial weight wet $(\mathrm{g}) \times$ concentration in $\mathrm{N}$ initial (wet, g/g).

\subsection{Chemical analyses}

CP content (Nx6.25) of experimental feeds, shrimp and feces samples was determined using the Kjeldahl-N method and gross energy (GE) determined using an adiabatic bomb calorimeter (Parr micro-calorimeter 1431, Parr instrument, Moline, Illinois).

\subsection{Energy Budget}

The information from the feeding trial was integrated to construct a detailed energy budget following the nomenclature proposed by the U.S. National Research Council (NRC, 1981). It was based on energy partitioning scheme taking into account several steps. Intake in gross energy (IE), digestible energy (DE or DEI for digestible energy intake), metabolizable energy (ME), urinary and branchial excretion (UE+ZE). Basal metabolism (HeE) was determined in the metabolic chamber.

Calculations of the difference between the estimated digestible nitrogen intake and the amount of nitrogen retained (Cho and Kaushik, 1990) were based upon an energy loss for ammonia obtained with the coefficient $24.9 \mathrm{~kJ} \mathrm{~g}^{-1} \mathrm{~N}$. 


\subsection{Statistical analyses}

All statistics were run using one-way Anova (Statview, Abacus concepts). Applicability of Anova was previously tested considering the normality of residues. One-way Anova was used when the answer was not following a dose/effect response. The studied factor was $\mathrm{CP}$ level as an independent variable and variables examined were gradually increasing.

\section{Results}

Survival rates averaged $75 \%$ and were not influenced by dietary treatment ( $p>0.05)$. Daily feed intake was calculated at $0.7 \mathrm{~g}$ shrimp ${ }^{-1} \mathrm{~d}^{-1}$ (range $0.7-0.9$ ). In spite of a certain imprecision on feed intake estimation, a curve was plotted for each diet showing the 50d experiment and there was no difference Fig.1).

Shrimp molt frequency mirrored weight gain in grams and it varied from less than a molt animal ${ }^{-1} 50 \mathrm{~d}^{-1}$ fed $25 \%$ CP up to 2 molts animal $^{-1} 50 \mathrm{~d}^{-1}$ fed $58 \%$ CP (Fig. 3).

Weight gain was appeared to be positively correlated to dietary protein content. Growth rates of shrimp were following a linear augmentation with dietary protein. It ranged from 3 to $7.5 \mathrm{~g}$ in 50d. (Fig.2). Final biomass obtained was in the same range of variation as weight gain with highest values at 52 and $58 \% \mathrm{CP}, \mathrm{p}<0.05$ (Table 1). Feed conversion ratio, FCR (dry feed consumed : wet weight gain) decreased linearly from 13 to 4.9:1, when CP level increased from 25 to $58 \%$ CP respectively (Table 5).

Apparent digestibility coefficient (ADC) of protein was about $90 \%$ and that of energy about 82\%.

Values of fasting oxygen consumption given (Table 4) were 0.8 to $1.2 \mathrm{mg} \mathrm{O}_{2} \mathrm{~g}^{-1}$ dry weight (dw) $\mathrm{h}^{-1}$ with 25 and $58 \% \mathrm{CP}$ respectively. After feeding, $\mathrm{O}_{2}$ values increased to $24-22 \mathrm{mg} \mathrm{O}_{2}$ live shrimp ${ }^{-1} \mathrm{~h}^{-1}$ with 25 and $58 \% \mathrm{CP}$, respectively. Conversion of $\mathrm{mg}$ $\mathrm{O}_{2}$ into energy consumed (Table 4) showed a metabolic rate comprised between 5-6 $\mathrm{kJ}\left(\mathrm{kg}^{0.8}\right)^{-1} \mathrm{~d}^{-1}$. An increase in dietary protein did not affect significantly HiE, even though $\mathrm{HiE}$ values with shrimp fed $52 \% \mathrm{CP}$ were 2 -fold greater than that observed in shrimp fed $29 \%$ CP (Fig. 4). HeE was stable and did not change significantly $(p<0.05)$ when shrimp were fed any of six experimental feeds (table 6).

$\mathrm{N}$-ammonia production curves peaked about $2 \mathrm{~h}$ after the meal distributed in the metabolic chamber. Dietary protein origin exerted a direct influence on $\mathrm{N}$-ammonia production (Fig. 3) with a range of $0.1-0.2 \mathrm{mg}-1 \mathrm{~g}-1 \mathrm{dw}$ (basal). In fasting state and $0.28-0.47 \mathrm{mg} \mathrm{g}^{-1} \mathrm{dw}$ in fed state for 25 and $58 \%$ treatments respectively (Table 3). Another expression of the result is $1.46 \mathrm{mg} \mathrm{N}$-ammonia shrimp-1 day-1 measure in unfed state after receiving the $25 \% \mathrm{CP}$ treatment for 50 days (table 3 ) and $3.7 \mathrm{mg} \mathrm{N}$ ammonia shrimp-1 day ${ }^{-1}$ measure in fed state after receiving the $25 \%$ CP treatment for 50 days. Similar calculation with $58 \%$ CP treatment gave 2.6 and 6.2 for unfed and fed states respectively.

O:N ratio (Figure 4) showed a decaying curve with increasing level of dietary protein. Carcass analyses are given on shrimp receiving each diet at the beginning and at end of the experiment (Table 4). From data including weight gain and carcass composition (Table 5) it was calculated that shrimp utilized nitrogen in a range of 10$15 \%$ of intake and retained energy at $7-17 \%$ of DE according to the level of dietary protein intake. Energy partitioning (table 6) was calculated for seven weeks of feeding to compare the different compartments of energy expenditure (kJ shrimp $\left.{ }^{-1}\right)$ and respective variations according to dietary protein levels. Higher recovered energy level $(45 \mathrm{~kJ})$ coincided with maximum growth $(7.5 \mathrm{~g}$ weight gain) obtained with diet $58 \%$ CP. A comparative table from several experiments conducted in the 
laboratory in the same conditions and the same species is given for the range of variations that can be found in respirometry chamber.

Carcass composition did not show difference on moisture content $(-75 \%)$ from initial to final stages or between treatments (Table 3). It is in agreement with the fact that energy density $\left(4.8 \mathrm{~kJ} \mathrm{~g}^{-1}\right)$ remained pretty much constant. Protein content decreased at end of the trial but remained unchanged whatever feed composition.

\section{Discussion}

a) During feeding experiments with six different compounded feeds, weight gain was quite high compared to results obtained in semi-intensive conditions (Mermoud et al., 1998). Also, weight gain were considered particularly good especially at 58\% CP with $1.1 \mathrm{~g} \mathrm{wk}^{-1}$ because taking into account the large size of animals, it used to be a level-off growth curve above $20 \mathrm{~g}$. In the course of growing experiment in tanks for $35 \mathrm{~d}$ molt control was evidently less accurate than in $4 \mathrm{~L}$ microcosm but never showed any abnormal situation even though survival rate hardly exceeded $80 \%$. Growth rates and molting performances (Fig 2) were significantly lower at low than at high protein level and it evidenced the fact that protein-sparing effect was not evidenced at the difference with lobster juvenile (Capuzzo and Lancaster, 1979). This absence of response can be related with consanguinity level (25 generations in captivity) of L.stylirostris and a subsequent decrease in allelic frequency on amylase genes leading to a poor carbohydrate utilization. Another species L.vannamei presenting a high inbreeding (27 generations, the most domesticated peneid strain in the world) raised in captivity at Ifremer/COP, lost ability to spare protein with carbohydrates when compared to wild specimen (Arena, 2004). Moreover, rather than carbohydrates (Cousin, 1995) or lipids (Cuzon and Guillaume, 1997), shrimp appeared to derived more efficiently energy from protein. The relative high protein/essential amino acid requirement of shrimp or fish derives from failure of deaminating enzymes to adapt to changes in dietary protein and a lower need for non-protein energy (Cowey, 1992, pers.com.).

Feed intake currently remained with a part of personal estimation even though an attempt with marker (Amouroux et al., 1997) gave some precise indication. In the course of experiment by daily observations that contributed for a large part to imprecision linked with FCR. Feed was largely available to avoid a limitation due to inadequate rationing day after day. But, in turn, it explains also the poor FCR that is common in small volume experimental tanks run in clear water, and feed given in excess. That is why a sub-satiation feeding strategy was the rule in nutrition experiments with lobster (Smith et al., 2003).

b) during metabolic measurements it is only at microcosm level with a set of 3 shrimp placed in 20-L volume that a fair estimate of intake (here around $0.6 \mathrm{~g} \mathrm{day}^{-1}$ shrimp $^{-1}$ ) was obtained to run calculations on energy budget. In a microcosme, cannibalism is inevitable however it remained a side problem with shrimp placed into the metabolic chamber. It was at once detectable while monitoring $\mathrm{O}_{2}$ consumption; then data were left aside for final calculations. Measurements made in the respirometer, for short period of few hours, led to an appreciation of each level of energy expenditure. Postprandial excretion (UE+ZE) and heat increment (HiE) results were similar in trend to those measured in L. setiferus, L. schmitti, F. duorarum and F. notialis postlarvae using purified diets containing $40,50,60$ or $65 \%$ protein (Rosas et al., 1996). HiE increased obviously with increasing dietary protein level but the contribution to HiE changed in a wide range with lesser values for $L$. setiferus and greater ones for F. duorarum. Intermediate values were observed in L. schmitti and $F$. notialis indicating that energy invested by each species in post-absorptive process is related to protein requirement. A large loss of energy through $\mathrm{HiE}$ can be 
explained from multiple ways and reference to deamination is an old concept that is proved false today. Several explanations could be put forward such as a rapid growth and a low maintenance, a recovered energy (RE) mainly used for body protein synthesis. Metabolism is terms of maintenance (HeE) did not change at high dietary protein levels but high $\mathrm{CP}$ resulted in high RE. Following this concept, efficiency of amino acids would be higher than lipids or carbohydrates (Guillaume, pers. com.). However for energy budget it was possible to get enough accuracy to get retained energy (RE). Retained energy (15\% DE) calculated on L.stylirostris post juveniles was lower than previous values (20-22\% DE) obtained after 28d trial using similar feeds (Cousin, 1995). Carcass composition provided an idea of protein deposition and, of course, the more nitrogen retained (RN) in the body the more growth. It was in concordance with previous authors data (Corraze, 1994) or slightly below (Cousin, 1995). RN was slightly above 15\% N intake, taking into account losses in feces, in urine and in cast (exuvia) and below what is used to be found in fish. This work provided values on retained energy and nitrogen that were around $11 \%$ and $15 \%$ respectively. Each value was similar with what was measured on other crustacean species under tropical conditions. Low ammonia wastes while shrimp were fed low protein content feeds coincide with the carnivorous habit of a domesticated strain such as L.stylirostris that is a reference in terms of growth performance for protein dense feed (Martinez-Cordova et al., 2003). An increase in crude protein (CP) induced growth, lowered FCR and increased retained energy. Therefore, energy derived from protein seemed better utilized that the one derived from other nutrients. Dietary starch around 20\% gave optimum utilization (Cuzon et al., 2000). There is an adequate use of carbohydrates under wheat starch form; a use of a starch with a high ADC value seems a prerequisite. A high digestive value of starch will be necessary both to spare protein and limit wastes while feeding on a $40 \%$ CP formulated feed sustaining optimum weight gain for L.stylirostris. L.vannamei juveniles fed semi purified diets with $10-20 \%$ cornstarch gave a high weight gain but it dropped above $25 \%$ incorporation (Guo et al., 2006). Cornstarch was found with a lower ADC (80\%) than wheat starch (Cousin, 1995) then the limit of inclusion could $30 \%$ or more with wheat starch. Fed in early larval stages, it would prepare juveniles to maximize the use of low pollution feeds. Such feeds would provide cheap digestible energy source and reduce $\mathrm{N}$-ammonia output.

c) O:N varied from 12 to 21 in a given range of dietary protein content. L.stylirostris that is mainly carnivorous++ presented a fluctuation of O:N according to dietary protein. An absence of significant variation with dietary protein levels could result from an absence of sufficient replicates to show clearly the trend. Each time revealing anyway that protein was main substrate in relation to a high protein level. It could reflect a high requirement for essential amino acids. Energy metabolism through calculation of $\mathrm{O}: \mathrm{N}$ ratio gives valuable indication on the degree of protein utilisation under different feeding conditions. Dietary protein varying from 23 to $35 \%$ changed metabolic activity of lobster larvae (Capuzzo and Lancaster,1979); starvation with zoopankton (Mayzaud and Conover,1988) or L.vannamei juveniles (Comoglio et al.,2004) or P. esculentus (Dall and Smith, 1986) brought O:N 3-9. Later on, a relation between protein level and O:N was evidenced in four shrimp species (Rosas et al., 1995). Different grades of omnivory according to species were observed in L. setiferus (omnivorous-herbivorous++), L. schmitti (omnivorousherbivorous+l_), F. duorarum (omnivorous+l_) and F. notialis (omnivorouscarnivorous++). Again, with L.setiferus and L.vannamei (Rosas et al.,2001), O:N ratio showed an amplitude of variation linked to a species-specific response. L.setiferus exhibited a constant utilisation of protein $(\mathrm{O}: \mathrm{N}<20-25)$. By contrast, L.vannamei fed high starch (hcbh) used carbohydrates as an energy substrate (O:N ratio 120).

At low plane of nutrition (amount of total digestible nutrients/total nutrients for maintenance), carbohydrates might be a useful energy source as it is the case with 
L. stylirostris wild strain. At high plane of nutrition a low amount of starch is utilized. Also, a difference was evidenced between wild and domesticated white shrimp for its utilization (Arena, 2004).

Finally the response of L.stylirostris to dietary alteration is such that performances are still acceptable in a wide range of protein levels tested and in a large range of average body weight $(5-30 \mathrm{~g})$ as soon as reproduction is not concerned. Any supplementation of crystalline amino acid still cause problem in terms of absorption. However, L-lysine or methionine and threonine which could be limiting factor at low protein level (meaning a low fish meal content) are to be further examined in terms of potent additive on a grower feed. However, energy budget remains as a main asset to provide support in case of further feed rationing model in large ponds during a whole growing cycle (Bureau et al., 2000).

\section{Conclusion}

Shrimp grew quite well in spite of the large initial size. Shrimp grew faster with high $\mathrm{CP}$ content than low one. They excreted more $\mathrm{N}$-ammonia after with a high dietary $\mathrm{CP}$. The hydrolysis of protein is probably efficient due to the quality protein of the feed. Amino acids were deaminated and carbon skeleton went for energy. Energy derived from protein is especially well utilized by shrimp through the phosphorylation chain. ATP that is available through this pathway seems definitely better utilized for further synthesis than energy coming from glucose or fatty acids. Similar conclusions were reached when studying fish. Domesticated shrimp receiving low CP and high starch content seems to utilize efficiently the feed at a low level and would face a double handicap: less protein, less amino acid for catabolism and excess of glucose.

\section{Acknowledgements}

Authors are very much indebted to Ingrid Mascher for her help with manuscript revision and Claude Soyez for his technical assistance with the respirometry work.

\section{References}

Amouroux, J.M., Cuzon, G. and Gremare, A., 1997. Association of pulse chase design, compartmental analysis and analogue modelling to assess absorption and assimilation efficiencies in $P$. stylirostris fed an artificial diet. Aquaculture 149(1-2): 71-86.

Arena, L., 2004. Polymorphism of $\alpha$-amylase on L.vannamei and incidence of starch on growth and metabolism. Thèse EPHE, Concarneau, 192 pp.

Bureau, D.P., Azevedo, P.A., Tapia-Salazar, M., and Cuzon, G. 2000. Pattern and cost of growth and nutrient deposition in fish and shrimp: potential implications and applications. In: Cruz-Suárez, E., Ricque-Marie, D., Tapia-Salazar, M. and CiveraCerecedo, R. (Eds). Avances en Nutrición Acuícola V. Memorias del V Simposio Internacional de Nutrición Acuícola, 19 al 22 de Noviembre , 2000, Mérida Yucatán, México 2000, 111-140.

Bureau, D.P., S.J. Kaushik, and C.Y. Cho. 2002. Bioenergetics. Pages 1-53 in Fish Nutrition. J.E. Halver, and R.W. Hardy, eds. Academic Press, San Diego, California. 
Burford M.A. and Williams K.C. 2001. The fate of nitrogenous waste from shrimp feeding. Aquaculture 198, 79-83.

Capuzzo J. M., Lancaster B. A., 1979. Larval development in the American lobster: changes in metabolic activity and the O:N ratio. Can. J. Zool. 57, 1845-1848.

Cho C.Y. and Kaushik S.J. 1990. Nutritional energetics in fish: energy and protein utilization in rainbow trout (Salmo gairdneri). In: Bourne, G.H. (ed.), Aspects of food production, consumption and energy values. World Rev. Nutr. Diet. Karger, Basel, $61,132-172$

Cho, C.Y.1991. Prediction model for energy requirement of salmonid fishes. Pages 446-449. In Proceedings of the $12^{\text {th }}$ Symposium of Energy Metabolism of Farm Animals. Kartause Ittingen, Zurich, Switzerland. C. Wenk, and M.Boessinger, eds. EAAP Publ. $n^{\circ}$ 58. Institute fur Nutztierwissenschaften, Gruppe Ernahrung, Zurich, Switzerland.

Cho, C.Y. and Bureau, D.P. 1998. Development of bioenergetic models and the Fish-PrFEQ software to estimate production, feeding ration and waste output in aquaculture. Aquat. Liv. Res. 11, 199-210.

Comoglio L I., Gaxiola, G., Roque A, Cuzon G, and Amin O., 2004. Effects of starvation on re-feeding, digestive enzymes activity, $\mathrm{O}_{2}$ consumption and ammonia excretion in the juvenile white shrimp, L. vannamei. J. Shell. Res. 23(1): 243-249.

Corraze, JL.1994. Mise au point d'un système de respirométrie continue. Evaluation sur un bivalve Pinctada margaritifera et un crustacé P.stylirostris. Mémoire ingénieur techniques agricoles, Bordeaux, 104pp.

Cousin, M., 1995. Contribution à l'étude de l'utilisation des glucides et du rapport P/E chez P.vannamei et P.stylirostris. Thèse INA / PG, Paris, 201pp.

Cousin, M., Cuzon, G., Guillaume, J., Aquacop 1996. Digestibility of starch in $P$. vannamei: in vivo and in vitro study on eight samples of various origin. Aquaculture 140(4): 361-372.

Cui, Y., and S. Xie. 1999. Modelling growth in fish. Pages 413-434 in Feeding Systems and Feed evaluation Models. M.K. Theodorou, and J. France, eds. CAB International, Wallingford, UK.

Cuzon, G., Guillaume, J. 1997. Energy and protein:energy ratio. In: D'Abramo, L.R., Conklin, D.E., and Akiyama, D. M. Crustacean Nutrition, Advances in World Aquaculture, vol.6, World Aquaculture Society, Baton Rouge, Louisiana, U.S.A., pp.51-70.

Cuzon,G., Rosas, C., Gaxiola, G. And van Wormhoudt, A., 2000. Utilization of carbohydrates by shrimp. 6th. Simposium Internacional de Nutricion Acuicola,La Merida; Yucatan, Mexico,15-18 november 2000, 7pp.

Dall,W.,1986. Estimation of routine metabolic rate in a peneid prawn P.esculentus Hasell. J. Exp. Mar. Biol. Ecol.96, 57-74.

Dall, W. and Smith, D.M., 1986. Oxygen consumption and ammonia-N excretion in fed and starved tiger prawns $P$. esculentus Haswell. Aquaculture 55, 23-33. 
Elliot, J.M. and Hurley, M.A. 1999. A new energetics model for brown trout, Salmo trutta. Fresh. Biol. 42, 235-246.

Gaxiola G., Gallardo P.P., Ravallec, R., Durruty, C., Martinez, G., Brito, A., Garcia, T., Cuzon, G., and Pedroza-Islas, R., 2002. Avances en el uso de alimentos en la camaricultura del camaron. Memorias del VI Simposio Intl de Nutricion Acuicola, Cancun, Quintano Roo, 13-16 septiembre, Univ. Autonoma del Nuevo León, México.

Guo, R., Liu, YJ., Tian, LX. And Huang, JW. 2006. Effect of dietary cornstarch levels on groqth performance, digestibility and microscopic structure in the white shrimp, $L$. vannamei reared in brackish water. Aquacult. Nut. 12: 83-88.

Hewitt D.R. and Irving M.G., 1990. Oxygen consumption and ammonia excretion of the brown tiger prawn $P$. esculentus fed diets of varying protein content. Comp. Biochem. Physiol. 96(3): 373-378.

Kaushik, S.J. 1998. Nutritional bioenergetics and estimation of waste production in non-salmonids. Aquat. Liv. Res. 11, 211-217.

Koshio S, Teshima S-I. and Kanazawa A., 1993. The effect of dietary protein content on growth, digestion efficiency and nitrogen excretion of juveniles kuruma prawn, P.japonicus. Aquaculture 113 (1-2): 101-114.

Lupatsch, I., G.W. Kissil, D. Sklan, and Pfeffe, E. 1998. Energy and protein requirements for maintenance and growth in gilthead sea-bream (Sparus aurata L.). Aquacult. Nutr. 4, 165-173.

Marsh A.G., Cohen S. and Epifanio C.E., 2001. Larval energy metabolism and physiological variability in the Asian shore crab Hemigrapsus sanguineus. Mar. Ecol. Prog. Ser. 218, 303-309.

Martinez-Cordova, LR., Campana Torres, A. and Porchas-Cornejo, MA. 2003. Dietary protein level and natural food management in the culture of blue ( $L$. stylirostris) and white shrimp (L.vannamei) in microcosms. Aquacult. Nut. 9: 155-160.

Mayzaud, P. and Conover, R. J. 1988. O:N atomic ratio as a tool to describe zooplankton metabolism. Mar. Ecol. Prog. Ser. 45, 289-302.

Mermoud, I., Costa, R., Ferre, O., Goarant, C. and Haffner, P. 1998. "Syndrome 93" in New Caledonia outdoor rearing ponds of $P$. stylirostris: history and description of three major outbreaks. Aquaculture 164(1-4): 323-335.

NRC, 1981. Nutrient Requirements of Fish. National Research Council, Washington, DC: National Academy Press.

Nelson, S.G., 1977. Calorie, carbon and nitrogen metabolism of juvenile Macrobrachium rosenbergii (de Man) (Crustacea, Palaemonidae) with regard to trophic position. Comp. Biochem.Physiol., 58A(3): 319-327.

Ocampo. V. L.,1998. Metabolizable energy and growth efficiency of the shrimp under the effect of environmental variations. $4^{\text {th }}$ Simposium Internacional de Nutricion Acuicola, La Paz, Baja California Sur, Mexico,15-18 november 1998, pp. 44-60. 
Read, G.H.L. and Caulton, M.S., 1980. Changes in mass and chemical composition during the moult cycle and ovarian development in immature and mature P.indicus Milne Edwards. Comp. Biochem. Physiol. 66A, 431-437.

Rosas, C., Sánchez, A., Díaz, E., Soto, L., Gaxiola, G., Brito, R., Baes, M.I., and Pedroza,R., 1995. Oxygen consumption and ammonia excretion of Penaeus setiferus, $P$. schmitti, $P$. duorarum and $P$. notialis postlarvae fed purified test diets: effects of protein level on substrate metabolism. Aquat. Liv. Res. 8, 161-169.

Rosas C., Sanchez A., Diaz E., Soto L.A., Gaxiola G., and Brito R., 1996. Effects of dietary protein level on apparent heat increment and post-prandial nitrogen excretion of Penaeus setiferus, $P$. schmitti, $P$. duorarum, and $P$. notialis postlarvae. J. World Aqua. Soc. 27, 92-102.

Rosas,C., Martinez,E., Gaxiola G., Díaz,E., Brito,R., and Soto,L., 1998. Effect of dissolved oxygen on the energy balance and survival of Penaeus setiferus juveniles. Mar. Ecol. Prog. Ser. 174, 67-75.

Rosas C., Cuzon G., Taboada G., Pascual C., Gaxiola G., and van Wormhoudt, A. 2001. Effect of dietary protein and energy levels (P/E) on growth, oxygen consumption, hemolymph and digestive gland carbohydrates, nitrogen excretion and osmotic pressure of $L$. vannamei and $L$. setiferus juveniles (Crustacea, Decapoda ; Penaeidae). Aquacult. Res. 32, 1-20.

Shiau, S.-Y., and Peng C-Y. 1992. Utilization of different carbohydrates at different dietary protein levels in grass prawn, Penaeus monodon, reared in seawater. Aquaculture 101, 241-250.

Sick, L.V., and Andrews J.W., 1972. The effect of selected dietary lipids, carbohydrates and proteins on the growth, survival and boby composition of $P$. duorarum. Proc.World Maricult. Soc. 4, 263-276.

Smith, DM., Williams, KC., Irvin, S., Barclay, M. and Tabrett, S. 2003. Development of a pelleted feed for juvenile tropical spiny lobster (Panulirus ornatus): response to dietary protein and lipid. Aquacult. Nut. 9: 231-237.

Solorzano, L. 1969. Determination of ammonia in natural waters by the phenol hypochlorite method. Limnol. Oceanogr.14, 799-801.

Statview, 1998. version Abascus Concepts version 5.0.

Stephenson and Stephenson MJ and Knight AW., 1980. The effect of temperature and salinity on $\mathrm{O}_{2}$ consumption of Pl's Macrobrachium rosenbergii de Man (Crustacea:Palaemonidae). Comp. Biochem. Physiol., 67A:699-703.

Weppe M, AQUACOP, Bonami, J.R, and Lightner, D.V.,1992. Demonstracion de las altas cualidades de la cepa de P.stylirostris SPR43 (Aquacop) resistente al virus IHHN. Memorias Primer congreso ecuatoriano de acuicultura, 18-23 oct.1992, Guayaquil, Ecuador.

Zhou, A., Xie, S., Lei, W., Zhu, X., Yang, Y. 2005. A bioenergetic model to estimate feed requirement of gibel carp, Carassius auratus gibelio. Aquaculture 248, 287-297. 
Table 1 Practical diets composition in \% as fed. ${ }^{(1)}$ Fish meal from Chili. ${ }^{(2)} \mathrm{CPSP}^{80}$ for fish soluble protein concentrate; ${ }^{(3)} \mathrm{SBM}$ for soybean meal ${ }^{48}$.

\begin{tabular}{|c|c|c|c|c|c|c|}
\hline & A & B & C & D & $E$ & $\mathrm{~F}$ \\
\hline${ }^{1}$ fishmeal & 10 & 18 & 24 & $3 ;$ & $4 C$ & 50 \\
\hline${ }^{2} \mathrm{CPSP}^{80}$ & - & 2 & 4 & 6 & 8 & 1( \\
\hline${ }^{3} \mathrm{SBM}^{48}$ & 1( & 11 & 18 & $1:$ & 14 & 15 \\
\hline wheat & $6\}$ & 57 & 47 & 35 & $2 i$ & 7 \\
\hline $\begin{array}{l}\text { wheat } \\
\text { gluten }\end{array}$ & 4 & 4 & 5 & 6 & 7 & 1( \\
\hline fish oil & 3 & 3 & 3 & 3 & 3 & 3 \\
\hline lecithin ${ }^{1}$ & 1 & 1 & 1 & 1 & 1 & 1 \\
\hline cholesterol & 0. & 0.2 & $0 .:$ & $0 .:$ & $0 .:$ & 0. \\
\hline vit $\mathrm{mix}^{2}$ & 2 & 2 & 2 & 2 & 2 & 2 \\
\hline $\min \operatorname{mix}^{3}$ & 2 & 2 & 2 & 2 & 2 & 2 \\
\hline moisture \% & 9, & 12,: & 9 & 9, & $9, i$ & 9,1 \\
\hline protein \% & $2 i$ & 29 & $3 i$ & 45 & $5 i$ & $5 \varepsilon$ \\
\hline DP & $2:$ & 27 & 34 & $4:$ & $4 \varepsilon$ & 54 \\
\hline lipid \% & 5 & 6 & 7 & 8 & 9 & 9 \\
\hline starch \% & 4 & 35 & $2 \varsigma$ & $2 i$ & 15 & 9 \\
\hline GE kJ/g & 19 & 19,1 & 19 & 19 & 20 & 20 \\
\hline $\mathrm{DE} \mathrm{kJ/g}$ & 1 & 14 & 15 & 16 & $1 i$ & 17 \\
\hline DP/DE g/ki & & 2 & 2 & 3 & 3 & 3 \\
\hline
\end{tabular}

${ }^{1}$ soybean lecithin: $65 \%$ phosphatids. ${ }^{2}$ vit mix: Rovimix 1730 Roche. in pure substance kg-1: A: $0.8 \mathrm{M}$ UI; $\mathrm{D}_{3}$ : $0.2 \mathrm{MUI}$; E: $10000 \mathrm{UI}$; Stay-C:1g; $\mathrm{B}_{1}: 0.07 \mathrm{~g} ; \mathrm{B}_{2}: 0.2 \mathrm{~g}$; $\mathrm{B}_{6}: 0.1 \mathrm{~g}$; PP:1g; $\mathrm{B}_{12}: 0.7 \mathrm{mg}$; menadione:58mg; panto Ca:50mg; folic ac.:4mg; biotin:0.4mg; inositol:1.4g; choline,3g. ${ }^{3}$ min mix: $\mathrm{NaH}_{2} \mathrm{PO}_{4}, \mathrm{KH}_{2} \mathrm{PO}_{4}$ (1:1).

DE from $35 / 23 / 15$ coefficients $\left(\mathrm{kJ} \mathrm{g}^{-1}\right)$ for lipid, protein and carbohydrate respectively (Cousin, 1995). 
Table 2. Growth performance and carcass characteristics of the shrimp fed experimental diets over a 7-week period (means, $\mathrm{n}=3$ ). Energy in $\mathrm{kJ}$ shrimp ${ }^{-1}$. RE for retained energy and DEI for digestible energy intake. HP: hepatopancreas.

\begin{tabular}{|c|c|c|c|c|c|c|}
\hline & 25 & 29 & 37 & 45 & 53 & 58 \\
\hline i wt, g shrimp-1 & $21+/-1$ & $21+/-1$ & $21+/-$ & $21+/-1$ & $21+/-$ & $21+/-$ \\
\hline f wt, g shrimp ${ }^{-1}$ & $25+/-1$ & $26+/-2$ & $25+/-$ & $27+/-2$ & $28+/-$ & $30+1-:$ \\
\hline feed g shrimp ${ }^{-1}$ & 35 & 35 & 35 & 35 & 40 & 35 \\
\hline \multirow[t]{2}{*}{ gain g shrimp ${ }^{-1}$} & $3.0+/-$ & $5.5+/-$ & $6+/-0$ & $5.9+/-$ & $7+/-0$ & $8+/-0$ \\
\hline & 1.5 & 0.4 & & 0.5 & & \\
\hline FCR & \multicolumn{2}{|c|}{$13+/-1.5 \quad 7.9+/-2.8$} & \multicolumn{2}{|c|}{$7.2+/-1.46 .4+/-1.6$} & $5.2+/-0.64 . \subseteq$ & $9+/-0.6$ \\
\hline HP index \% & 3.6 & & 3.2 & & & 3 \\
\hline N gain g shrimp & 0.06 & 0.09 & 0.06 & 0.17 & 0.16 & 0.21 \\
\hline $\mathrm{N}$ intake $\mathrm{g}$ shrim & 1.29 & 1.62 & 2.07 & 2.52 & 3.33 & 3.25 \\
\hline 1 & & & & & & \\
\hline gross energy initial & 100 & 99 & 99 & 99 & 99 & 99 \\
\hline gross energy final & 117 & 124 & 115 & 130 & 134 & 143 \\
\hline recovered energ. & 18 & 26 & 16 & 32 & 35 & 45 \\
\hline RE/DEI \% & 4 & 5 & 3 & 6 & 5 & 7 \\
\hline
\end{tabular}


Table. 3. Carcass composition \% live shrimp weight before and after 50 days feeding on the 6 diets (25-58\% CP named A to F). CP for crude protein. GE in $\mathrm{kJ} \mathrm{g}^{-1}$ live weight

\begin{tabular}{cccc}
\hline & water \% & CP \% & $\mathrm{kJ} \mathrm{g}^{-1}$ live weight \\
\hline initial & 75.3 & 19.7 & 4.8 \\
A & $71.6+/-12.6$ & 18.4 & 4.7 \\
C & $77.1+/-5.1$ & 18.3 & 4.7 \\
D & $76.5+/-4.4$ & 18.4 & 4.6 \\
E & $78.4+/-6.6$ & 18.9 & 4.7 \\
F & $70.6+/-3.2$ & 18.4 & 4.8 \\
& & 18.4 & 4.8 \\
\hline
\end{tabular}


Table 4. Variation of oxygen consumption ( $\mathrm{mg} \mathrm{O}_{2} \mathrm{~g}^{-1}$ dry matter) monitored on a $9 \mathrm{~h}$ period $\left(F=2.5, p=0.14\right.$ for HeE; $p=0.98$ for $\mathrm{HiE}$ ) and converted in $\mathrm{J} \mathrm{g}^{-1}$ live weight $\mathrm{h}^{-1}$ according to dietary protein levels. (mean+l-S.E).

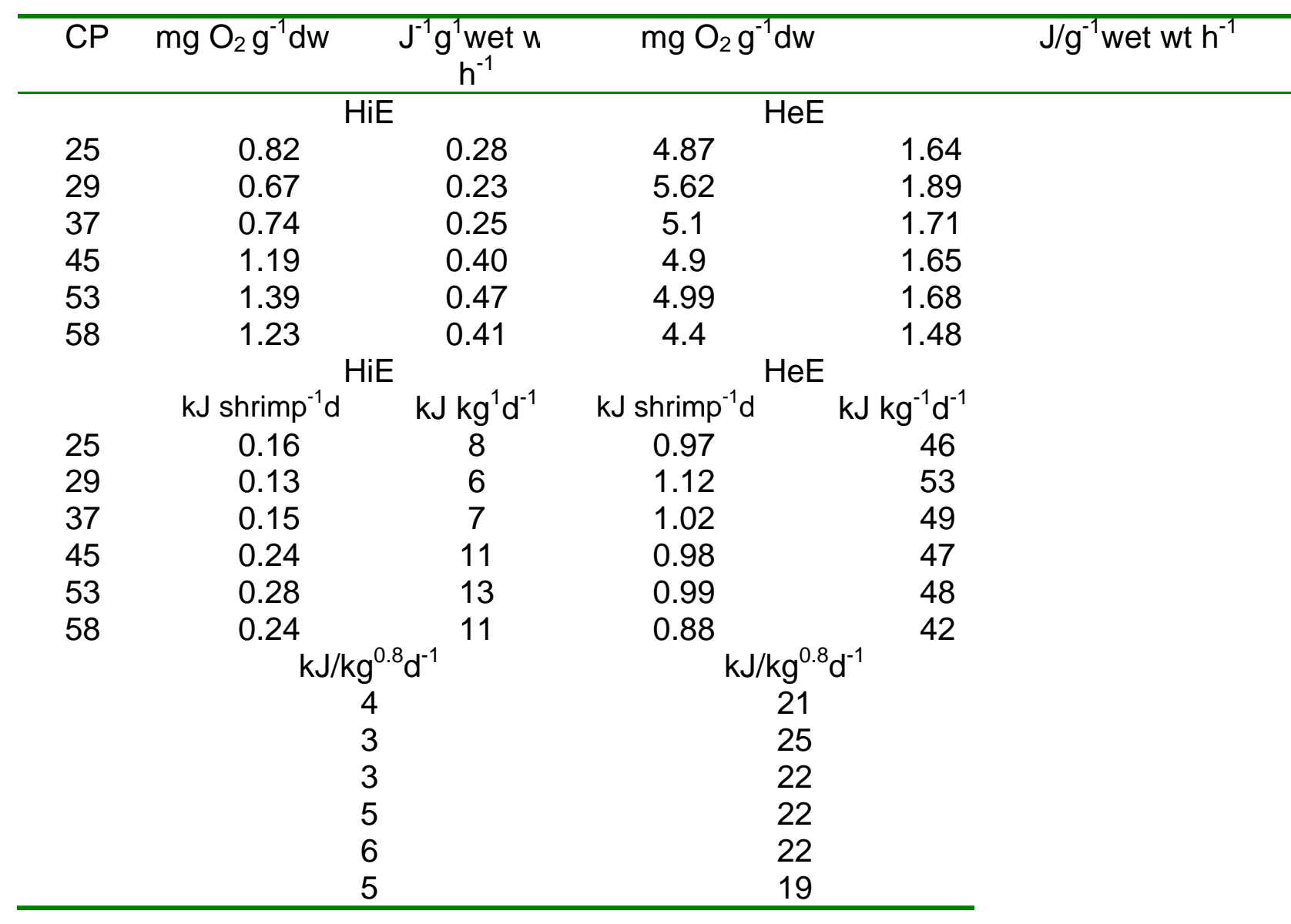


Table. 5. Variation of ammonia ( $\mu \mathrm{g} \mathrm{N}$-ammonia $\mathrm{g}^{-1}$ dry weight $\mathrm{mn}^{-1}$ ) and converted to J. shrimp ${ }^{-1}$ day $^{-1}$ for a $9 \mathrm{~h}$ period according to dietary protein levels. (CP: crude protein; rep.:replicate).

\begin{tabular}{clccc}
\hline & & fasting & postprandial & fed \\
\hline$\%$ CP & rep. & $\mu \mathrm{g} / \mathrm{g}$ & $\mu \mathrm{g} / \mathrm{g}$ & $\mu \mathrm{g} / \mathrm{g}$ \\
25 & 3 & 0.11 & 0.17 & 0.28 \\
29 & 3 & 0.17 & 0.19 & 0.37 \\
37 & 2 & 0.17 & 0.19 & 0.36 \\
45 & 3 & 0.28 & 0.26 & 0.54 \\
53 & 3 & 0.13 & 0.48 & 0.60 \\
58 & 3 & 0.2 & 0.26 & 0.47 \\
F Fischer & & 0.46 & 9.7 & 5.28 \\
$p$ & & 0.5 & 0.01 & 0.04 \\
& & & UE+ZE(J shrimp ${ }^{-1}$ day $^{-1}$, & \\
25 & & 14 & 24 & 38 \\
29 & & 24 & 28 & 52 \\
37 & & 24 & 28 & 52 \\
45 & & 43 & 42 & 85 \\
53 & & 28 & 80 & 98 \\
58 & & & 42 & 70 \\
\hline
\end{tabular}


Table 6. Energy budget (kJ) extrapolation for seven weeks with shrimp fed 6 different experimental diets. Mean values $(n=15)$.

\begin{tabular}{|c|c|c|c|c|c|c|}
\hline & \multicolumn{6}{|c|}{$\operatorname{diets}^{1}$} \\
\hline & $A$ & $B$ & C & $\mathrm{D}$ & $E$ & $\mathrm{~F}$ \\
\hline parameters & $25: 42$ & 29:36 & $37: 30$ & $45: 21$ & $53: 13$ & $58: 4$ \\
\hline IE & 568 & 612 & 655 & 682 & 850 & 725 \\
\hline $\mathrm{FE}^{2}$ & 113 & 122 & 130 & 122 & 170 & 130 \\
\hline DE intake & 455 & 490 & 525 & 560 & 680 & 595 \\
\hline$(U E+Z E)$ & 25 & 30 & 25 & 35 & 65 & 35 \\
\hline $\mathrm{HiE}$ & 93 & 83 & 83 & 137 & 162 & 137 \\
\hline HeE & 211 & 240 & 221 & 176 & 176 & 191 \\
\hline $\mathrm{SE}^{3}$ & 15 & 16 & 18 & 20 & 20 & 21 \\
\hline $\mathrm{RE}^{4}$ & 18 & 26 & 16 & 32 & 35 & 45 \\
\hline unaccounte & 93 & 95 & 162 & 160 & 222 & 166 \\
\hline 5 & & & & & & \\
\hline
\end{tabular}

1 Diet designation. A: $(25 \% \mathrm{CP})$ to $\mathrm{F}$ : $(58 \% \mathrm{CP}) .{ }^{2}$ based on calculated nitrogen losses only. ${ }^{3} \mathrm{SE}$ is calculated from the energy content of one exuvia time number of molts for the experimental period. ${ }^{4}$ recovered energy obtained by difference (IE-FE(UE +ZE)-(HeE-HiE)-RE) and therefore, includes unmeasured losses, and the errors from various other measurements. ${ }^{5}$ unaccounted: calculated using estimate of $\mathrm{HeE}$ from respirometry trial. 


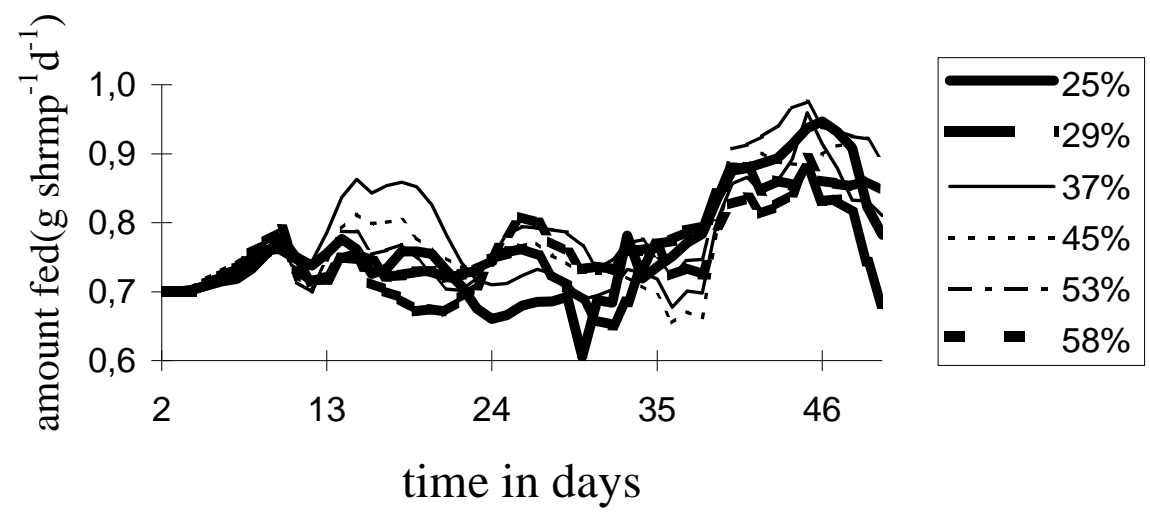

Fig. 1. Evolution of daily feed consumption all along the experiment when feeding shrimp different CP levels. 


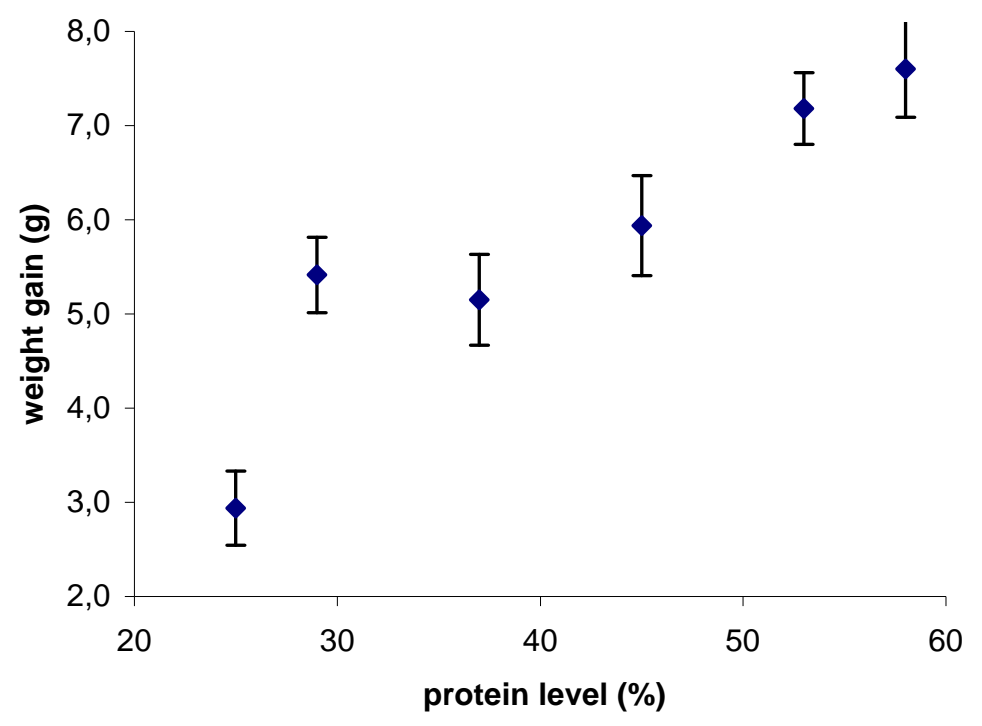

Fig. 2. Mean weight gain during 50 days with $21 \mathrm{~g}$ L.stylirostris fed six different diets. (error-bars=SD). 


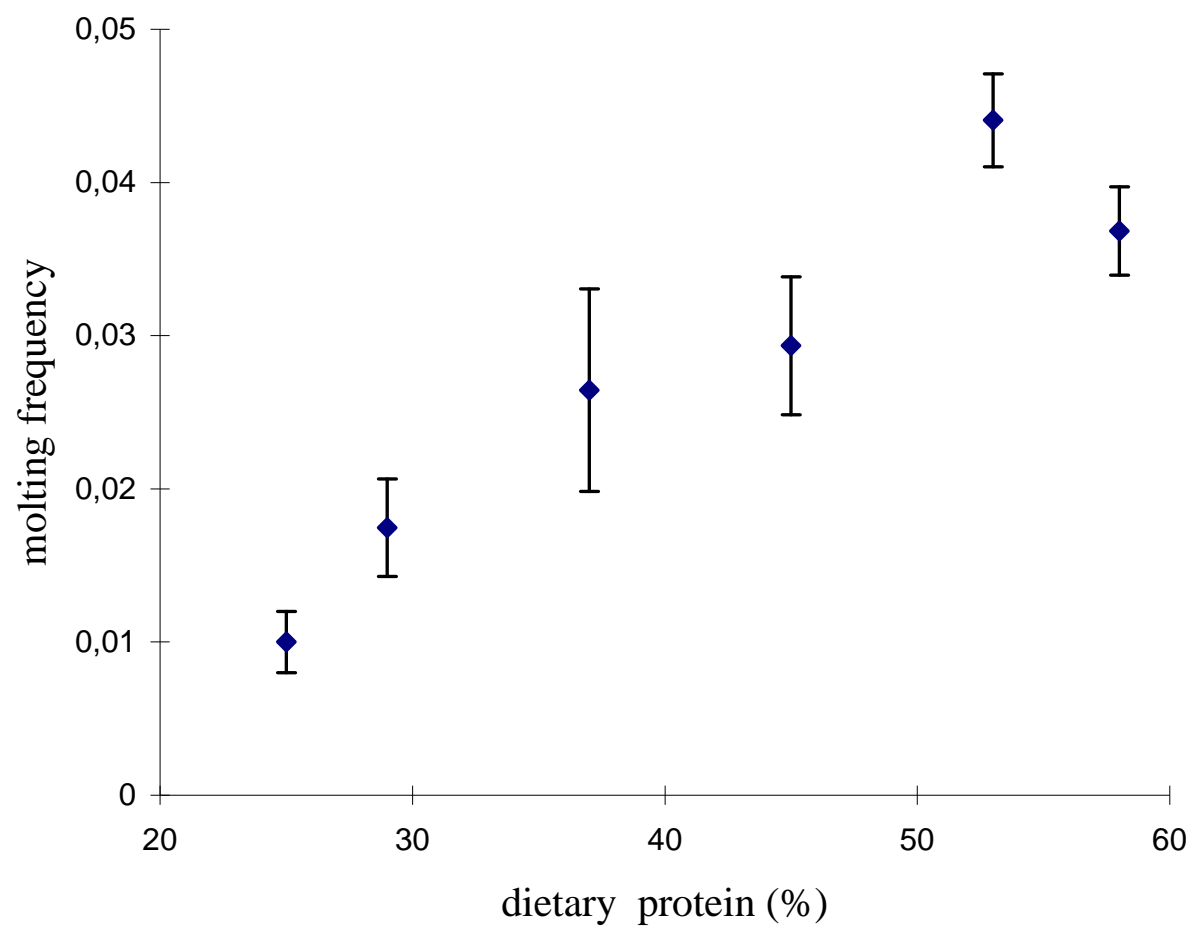

Fig. 3. Molting frequency (exuvia shrimp ${ }^{-1}$ day $^{-1}$ ) with L.stylirostris fed six different diets during a 50 days trial. (error-bars=SD). 


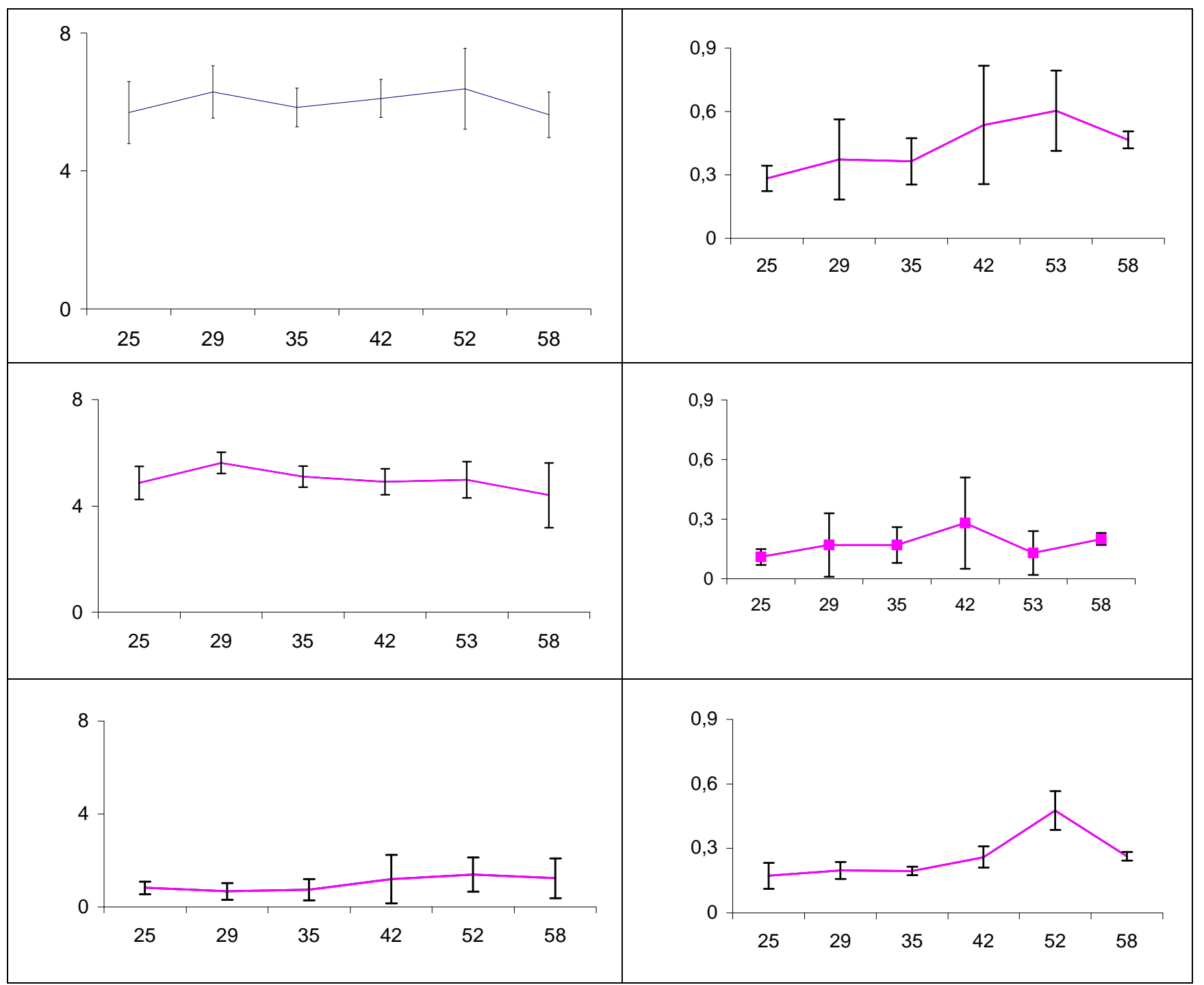

Fig. 4. Variations of oxygen and N-ammonia according to protein dense compounded practical feeds.

(mean+/-SD). Y-axis, $\mathrm{mg} \mathrm{O}_{2} \mathrm{~g}^{-1}$ dry shrimp weight $9 \mathrm{~h}^{-1}$ ). Dietary protein levels in abscissas.

Left column. a,b,c : top to bottom (a) $\mathrm{O}_{2}$ consumption ( $\mathrm{mg} \mathrm{g}^{-1}$ dry matter $9 \mathrm{~h}^{-1}$ ) fed shrimp. (b) post-prandial $\left(\mathrm{O}_{2}\right.$ consumption fed shrimp minus $\mathrm{O}_{2}$ consumption fasted shrimp (c) $\mathrm{O}_{2}$ consumption of fasted shrimp (basal).

Right column: d,e,f. : top to bottom (d) ammonia excretion ( $\mu \mathrm{g} \mathrm{g}^{-1}$ dry shrimp weight $\mathrm{mn}^{-1}$ ) expressed as routine excretion. (e) post-prandial level. (f) basal level. 


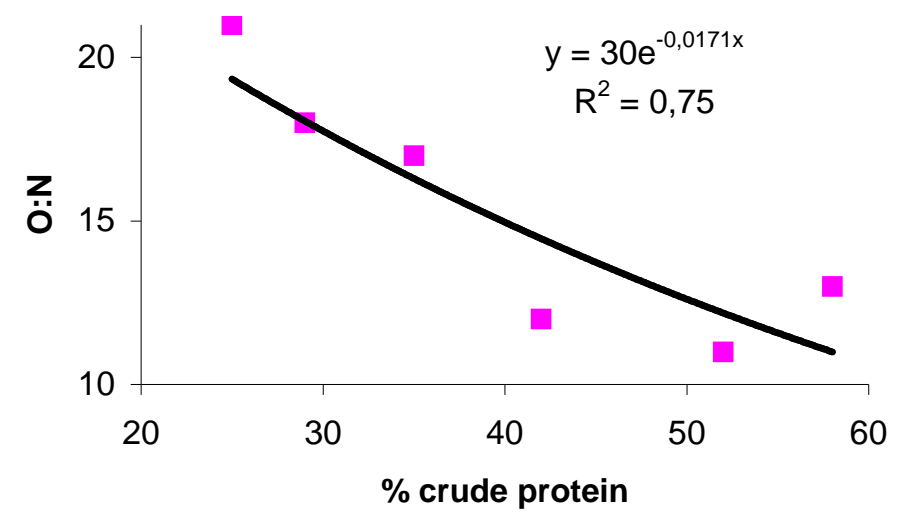

Fig 54. Effect of dietary protein levels (CP) on O:N ratio.Two groups, below $40 \% \mathrm{CP}$, $\mathrm{O}: \mathrm{N}$ indicated a mixed energy substrate, above 40\% CP all O:N 12 indicated protein as an energy substrate. 